\title{
Teacher Career Development Management at Madrasah Aliyah Negeri
}

\author{
Syafaruddin', Mesiono ${ }^{2}$, Indrasyah Sitompul 3 \\ DOI: 10.35445/alishlah.v13i2.759
}

\begin{tabular}{l} 
Article Info \\
\hline \\
Keywords: \\
Teacher Career; \\
Management; \\
Development
\end{tabular}

Kata Kunci:

Karir guru;

Manajemen;

Pengembangan

\begin{abstract}
This study aims to analyze the management of teacher career development at MAN 2 Model Medan. The research focuses on planning, organizing, implementing, and evaluating teacher career development at MAN 2 Model Medan. This study uses a qualitative approach with a descriptive-analytical study method. Obtaining data using observation techniques, interviews, and document studies. Furthermore, the data were analyzed using data reduction techniques, data presentation, and drawing conclusions or data verification. The results of this study indicate that the management of teacher career development at the MAN 2 Medan Model is carried out effectively. It can be viewed from the aspects; (1) planning for teacher career development in the form of motivation and application of a conducive organizational culture (climate); (2) organizing human resources (HR) for teachers in madrasah through leadership support, technical meetings, coordination between madrasah leaders and vice-principals involving supervisors to improve teacher qualifications; (3) the implementation of teacher career development is carried out based on promotion, transfer, and promotion; (4) evaluation of teacher career development is carried out based on online-based supervision and teacher performance assessment. This research hopes that it can be used as a reference for further research on the management of teacher career development in Islamic educational institutions. This research also has implications for teachers in Islamic educational institutions to accelerate careers as educators in madrasah.
\end{abstract}

\begin{abstract}
Penelitian ini bertujuan untuk menganalisa manajemen pengembangan karir guru di MAN 2 Model Medan. Fokus pembahasan penelitian meliputi aspek perencanaan, pengorganisasian, pelaksanaan dan evaluasi pengembangan karir guru di MAN 2 Model Medan. Penelitian ini menggunakan pendekatan kualitatif dengan metode studi deskriptif analitik. Pemerolehan data menggunakan teknik observasi, wawancara dan studi dokumen. Selanjutnya, data dianalisa menggunakan teknik reduksi data, penyajian data dan penarikan simpulan atau verifikasi data. Hasil penelitian ini menunjukkan bahwa manajemen pengembangan karir guru di MAN 2 Model Medan terlaksana dengan efektif, hal ini dapat ditinjau dari aspek; (1) perencanaan pengembangan karir guru dalam bentuk motivasi dan penerapan budaya (iklim) organisasi yang kondusif; (2) pengorganisasian sumber daya manusia (SDM) guru di madrasah melalui dukungan pimpinan, rapat teknis, koordinasi
\end{abstract}

\footnotetext{
${ }^{1}$ State Islamic University of North Sumatra, Medan, Indonesia

E-mail: syafaruddin@uinsu.ac.id

${ }^{2}$ State Islamic University of North Sumatra, Medan, Indonesia

E-mail: mesiono@uinsu.ac.id

3 State Islamic University of North Sumatra, Medan, Indonesia

E-mail: indrasyahsitompul2806@gmail.com
} 
antara pimpinan madrasah dengan wakil kepala madrasah melibatkan pengawas dalam upaya meningkatkan kualifikasi guru; (3) pelaksanaan pengembangan karir guru dilakukan berdasarkan kenaikan pangkat, mutasi, dan promosi; (4) evaluasi pengembangan karir guru dilakukan berdasarkan supervisi dan penilaian kinerja guru berbasis online. Melalui penelitian ini, diharapkan dapat menjadi bahan banding penelitian selanjutnya tentang manajemen pengembangan karir guru pada lembaga pendidikan Islam. Bahkan, penelitian ini juga berimplikasi bagi para guru di satuan lembaga pendidikan Islam, dalam upaya percepatan karir sebagai pendidik di madrasah.

\section{INTRODUCTION}

Quality is an "absolute price" that an educational institution unit cannot negotiate. Because quality is the "image of the institution," which is an attraction for the community, quality can generally be in the form of institutional services and "a reflection of graduates." For this reason, proper and integrated management is needed to create a superior institution of interest to the learning community (Dryden \& Vos, 2001: 408; Syafaruddin et al., 2020; Ramli, 2015). Concerning the quality of educational institutions, the professionalism of teachers is one of the main factors that must be prepared through objective recruitment according to the needs of students and institutional customers (Seprianti, 2012: 66; Ramli, 2017). It is based on the multi-role of the teacher in helping students reach a level of mental and mental maturity to face life's challenges (Sanjaya, 2009: 160; Assingkily \& Mesiono, 2019).

In reality, teachers are seen as figures who can educate, teach, and deserve to be trusted or trusted in helping the growth and development of children (students). The term teacher is widely interpreted by the community, starting from the meaning of the teacher as a teaching professional (educator) informal institutions (Ministry of National Education, 2000: 469), educators in houses of worship or private homes (Asmani, 2013: 20), all of which lead to efforts to help children (students) reach the level of maturity as individual and social beings (Syafaruddin et al., 2006: 5354). On this basis, the laws and regulations in Indonesia stipulate that teachers or educators must be professional and competent (Jawani, 2012: 36; Rosyada, 2017: 206). In this regard, it is clear that career development for teachers is necessary to answer and respond to the global community's needs to competent educators in every educational institution. Furthermore, Yanti et al. (2015: 1) concluded a significant relationship between career perceptions and teacher performance in the research. Because, through the context of career development, teachers will feel "uncomfortable" with their current potential but seek to improve their qualifications in teacher education.

A teacher's professional capacity is assessed through performance (Arman et al., 2016). This is certainly assessed by the madrasah/school leader, as a leader in the institution where the teacher teaches/serves (Okoroji et al., 2014: 181). According to Tan (2018: 21), the teacher is one of the principal's scopes of work objects because teacher career development needs support and effective management driven by the principal. The demands of career development for teachers cannot be avoided because teachers must always strive to adopt new developments, both in the field of information technology and community demands. In addition to these factors, curriculum changes from time to time are a challenge in teacher career development (Jawani, 2012: 120). Furthermore, integral considerations in career development include systematic, relevant, flexible, and innovative, physical and psychological conditions, and organizational management (Wardan, 2019: 94). Teaching as a teacher's primary task demands professional preparation and development and promises a future career (Orgovanyi \& Gajdos, 2016: 9). According to Semito (1992: 118), the form of career development can be done through 1) education and training, 2) promotion, and 3) transfer.

Indeed, studies on the management of teacher career development have been studied by previous researchers from various aspects. Among other things, covering aspects of principal madrasah support and regular training programs (As'ad, 2017: 36), educator career as madrasah supervisor (Rachmawati, 2019: 84), Islamic education HR career development management (Azhari 
\& Wicaksono, 2017: 96) and at the boarding school (Sarinah, 2016: 1). The gap analysis of this research with the previous one is the research background in MAN 2 Model with good teacher academic qualifications, the quality of graduates from institutions that excel in the national and international arena. In fact, according to an interview with Irwansyah (Head of MAN 2 Model Medan), that the enthusiasm for further studies of educators at MAN 2 Model Medan is very high (one of which is proven by a total of 37 teachers having master's degrees, following 30 teachers who are studying master's programs, even 2 teachers have graduated from Master's Degree Program). doctorate degree).

There is a vacancy in teacher career development management study from research background and teacher qualifications in a madrasa (especially MAN 2 Medan Model). For this reason, it is needed to analyze the management of teacher career development at MAN 2 Model Medan. Through this research, it is hoped that a complete concept will be obtained regarding efforts to improve the career of madrasa teachers through effective management and encourage adequate educational qualifications and soft skills of teachers in madrasas.

\section{METHODS}

This study uses a qualitative approach with a descriptive-analytical method (Sugiyono, 2010). The focus of the discussion is the management of teacher career development at MAN 2 Model Medan. The informants of this study included the Head of Madrasah (IW), Deputy Head of Madrasah (MS), and Teachers (MY, NS, IMT, PH) MAN 2 Model Medan. Data were collected using participant observation techniques, interviews, and document analysis. Furthermore, data analysis uses data reduction techniques, descriptive data presentation, and concluding. The validity of the research data was tested through triangulation techniques (methods and sources). Triangulation is meant as a form of data collection, which is then compared between one data with other data (interviewing one informant, with other informants) (Creswell, 2009). In this context, 2 (two) aspects of triangulation are compared, namely methods and data sources.

\section{FINDINGS AND DISCUSSION}

\section{Teacher Career Development Planning at MAN 2 Model Medan}

The initial process in carrying out the management function in teacher career development is the planning stage (Nadlir, 2013; Nurlaila, 2018). According to Prabowo (2010), this stage is the "starting footing or foundation" in directing and controlling the next stage in the management process cycle. Based on the description of the interview that the researcher conducted with the Head of MAN 2 Model Medan, that the career planning he did for the teachers was as follows:

"I think the teacher's motivation for a career at MAN 2 is very good. We know that many teachers at MAN 2 later turned into officials at the Regional Office, at the Regency Ministry of Religion. Some became lecturers, some became supervisors. So, it is really very thick here with teacher career development." (Results of interview with Irwansyah, MA, 22 October 2021, 12:46 A.M).

In line with the interview excerpt above, MS (Deputy Head of Madrasah for Curriculum Sector MAN 2 Model Medan), said:

"...yes sir, when asked about my career, I was actually formed because of the environment at MAN 2 Model Medan, sir, to be competitive and different from other teachers, so I initially tried to equip myself with knowledge regarding the field of study of science. society. Thank God, sir, the results are good sir, I can guide students to get the overall champion of the USU Olympics at the North Sumatra Province level. Although since Covid-19, student achievement has decreased somewhat due to the online learning system, sir. Likewise, we as teachers always try to provide conducive and close learning to students, so that students are happy, free, and focused on learning, sir." (Results of an interview with the Deputy Head of Madrasah for Curriculum Sector MAN 2 Model Medan, October 8 202O). 
The interview excerpt above informs that a conducive learning climate is a "meeting point" between teachers and students. This conducive learning climate will be realized through an effective organizational culture and career development management in the madrasah. According to Rifa'i \& Assingkily (2021), realizing a conducive learning climate requires the role of leaders through internal policies in educational institutions. Furthermore, NS (teacher of MAN 2 Model Medan) said:

"What I do is carry out my duties with discipline, have a high commitment to the task. Complete administrative duties as a teacher. Next is trying to become a professional teacher in the field of study. Then I want, strive and pray for my students to become successful people beyond my success." (Results of an interview with the Medan Model MAN 2 Teacher, Jurisprudence Subject, October 6, 2020).

Through the interview excerpt above, it can be seen that teachers at MAN 2 Model Medan prioritize their primary tasks as educators to teach, prepare teaching materials. There are efforts to help students develop and pray for students to become successful people in the future. Fauzi (2017) termed this kind of effort as a teacher's strategy to provide students career guidance. In the context of other teacher career development, MY (teacher of MAN 2 Model Medan) said:

"The effort I made in planning my career as a teacher was attending MGMP (Subject Teacher Consultation) discussions and making scientific papers carrying out research or CAR (Classroom Action Research)." (Results of an interview with the Medan Model MAN 2 Teacher, Subjects of the Qur'an Hadith, October 8, 2020).

The interview excerpt above confirms that doing scientific work is one of the indicators in developing a teacher's career. This is based on the function of research as a bridge between education and service (Wiganda, 2014; Assingkily \& Rohman, 2019; Assingkily, 2021). Furthermore, the career development pursued by IMT (teacher of MAN 2 Model Medan, Hadith Science Subject) is conveyed in the following interview excerpt:

"When I became a teacher, sir, from the beginning, I had planned to have an academic education, at least $S_{3}$, sir. So, Alhamdulillah, it was realized with a strong intention since I went to college. Then one more thing, I have to master the learning method. One thing I have to understand is sir, what I plan to do is to become a teacher, lest the students don't understand or don't understand the subjects I teach if there are things it will be uncomfortable "In my heart, sir." (Results of an interview with the Medan Model MAN 2 Teacher, Hadith Science Subject, November 19, 2020).

The interview excerpt above shows that one of the essential aspects of planning a teacher's career is taking further studies (education) and increasing one's professionalism as an educator. On this basis, madrasa leaders should support teacher career orientation through the establishment of internal institutional policies, as well as fostering relationships with various agencies for teacher career development (Wardani et al., 2021; Zulaikhah, 2014; Ramdani et al., 2019). Furthermore, the planning for teacher career development at MAN 2 Model Medan is shown in Figure 1. 


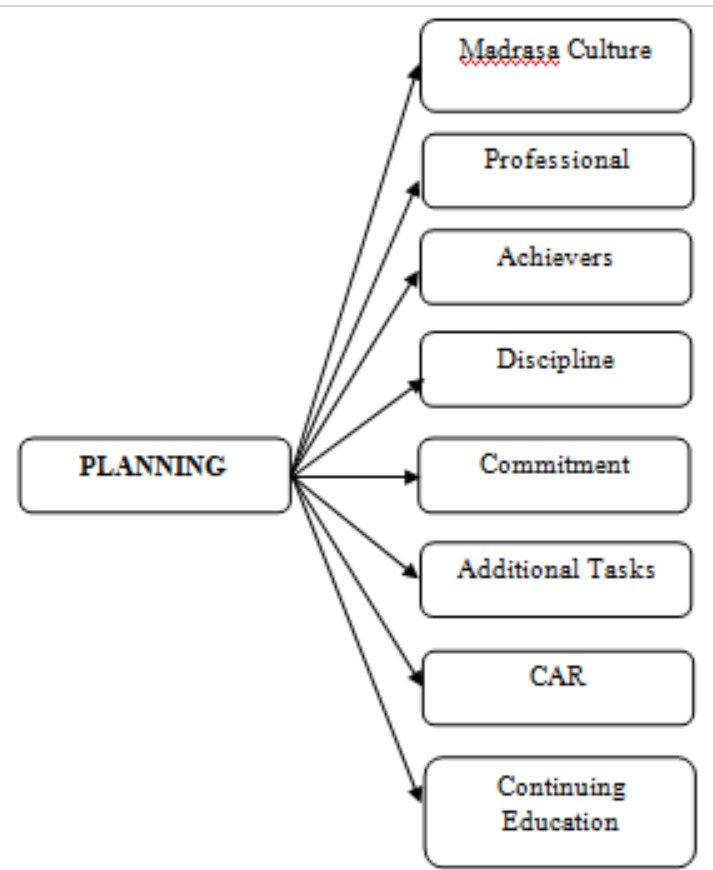

Figure 1. Teacher Career Development Planning MAN 2 Medan Model

Based on the description and picture above, it is understood that the planning of teacher career development at MAN 2 Model Medan includes 8 ways, namely motivation and career development culture in the madrasah environment, efforts to become professional teachers/educators, achievement motivation, discipline, commitment to the task and the mandate given by the teacher. The teacher is given, carry out additional tasks, conduct research (CAR), and pursue further education (advanced studies).

\section{Organizing Teacher Career Development at MAN 2 Model Medan}

In simple terms, organizing is a step in determining various kinds of activities based on the authority and main tasks, or commonly known as "who does what" (Saefrudin, 2017; Rachman, 2015; Rahmawati, 2018). In the context of this research, the organization in question is how the teacher career development process at MAN 2 Model Medan, the steps taken, and who is authorized to handle it. In this regard, the following is an excerpt from an interview with the Head of MAN 2 Model Medan who said:

"First, we have a meeting first. At the beginning of each semester, we hold a meeting of all teachers to discuss what will be done, including who wants to be promoted and so on. We also invite supervisors to give directions regarding the technical implementation." (Interview with Irwansyah, MA, 22 October 202O).

Supporting the above interview, MS (Deputy Head of Madrasah MAN 2 Model Medan) said:

"The leadership's efforts, if the teacher's career planning is actually a lot of starting from learning books, then olympiad books, that's what we ask for sometimes schools respond, especially from the committee that manages student finances. Well that's what helps too. Then I also had it because my administration was very difficult, it was the principal who previously gave me a laptop to develop our careers so that we could pass it on to our members. Alhamdulillah, yesterday our members majoring in geography for the national level have got gold. If that is the process, we start with ourselves in our career development." (Results of an interview with the Deputy Head of Madrasah MAN 2 Model Medan, October 8, 2020)

Based on the interview excerpt above, it is understood that the madrasah principal plays a very important role in assisting and facilitating the career development needs of teachers as potential human resources (HR) in MAN 2 Model Medan. In the view of Mrs. NS (teacher of MAN 2 Model 
Medan), that the organization of resources in teacher career development in the MAN 2 Model is carried out as follows:

"Efforts made by the leadership are holding official meetings at the beginning of each semester and presenting madrasa supervisors and madrasa committees in several official meetings. In addition, we participate in every training opportunity at the madrasah, district/city, provincial and national levels, then try to apply the training results in carrying out the duties of teachers. Trying to socialize the results of the training obtained and develop the results of the good training for MGMP teachers." (Results of an interview with the teacher at MAN 2 Model Medan, October 6, 2020).

The interview above indicates that apart from the central role and support from the principal in assisting teacher career development, regular meetings are also held at the beginning of each semester to discuss teacher career development specifically. Another thing that is also being sought is to invite madrasa supervisors to guide teachers in developing careers. In this case, the committee is also involved in the meeting-teachers who wish to develop a career seeking to undertake training and research at every opportunity. Then the results of the training and research were carried out and socialized to the Subject Teacher Conference (MGMP).

Meanwhile, according to Mr. MY ((teacher of MAN 2 Model Medan) that the organization of teacher career development resources is as follows:

"Madrasahs encourage teachers to actively fulfill work targets in making CAR that can

be used for promotion. School leaders or principals and curriculum when encourage all teachers to be active in attending MGMP discussions in each lesson." (Results of an interview with the MAN 2 Model Medan Teacher, October 8, 202O).

Based on the results of the interviews above, it can be stated that the organization of teacher career development resources at MAN 2 Model Medan is carried out by the head of the madrasa and coordinates with the deputy head of the madrasa in motivating teachers to actively carry out Classroom Action Research (CAR) and also actively participates in various discussions and discussions. Training supports teacher career development. This support is critical because it can create a compelling and advanced organizational climate. This support is not only in verbal motivation but also provides facilities and facilitates all matters related to the smooth process towards career development, both promotions and transfers to specific positions.

More details regarding the organization of resources in teacher career development at MAN 2 Model Medan can be seen in the following picture:

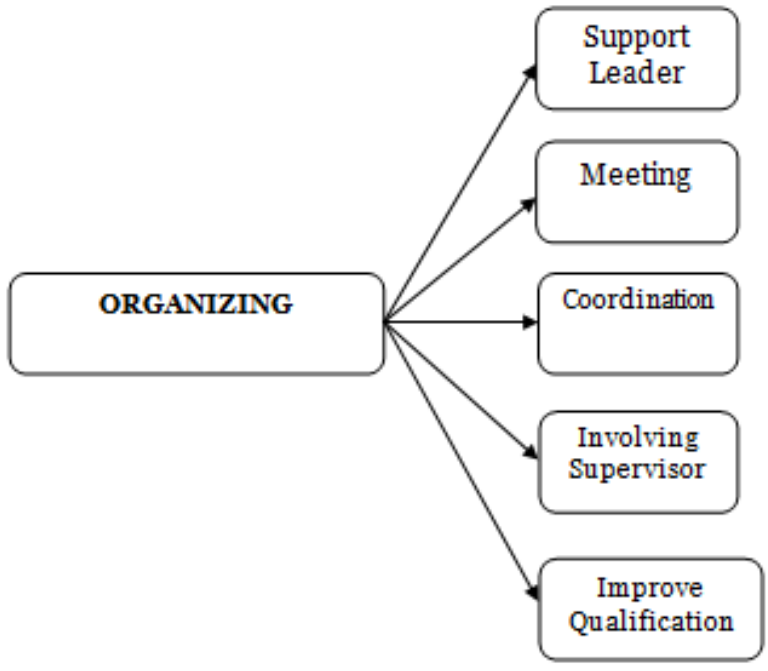

Figure 2. Organizing Teacher Career Development at MAN 2 Model Medan

The organization of human resources in the context of teacher career development at MAN 2 Medan Model includes 5 ways, namely leadership support for teacher career development, coordination between the head of the madrasa and deputy head of the madrasa, early semester 
meetings to discuss career development teachers, involving elements of madrasah supervisors, and increasing teacher qualifications (continuing studies) in career development efforts.

\section{Implementation of Teacher Career Development at MAN 2 Model Medan}

Implementation is the execution of planning and organizing that has been done (Rahayu \& Firmansyah, 2018). Based on the results of interviews with the head of MAN 2 Model Medan that the implementation of the teacher career development program is carried out as follows:

"Usually, our teachers get promoted. They propose first and have completed all the required documents such as PTK, for example. There is also our teacher who has moved to become a supervisor. The same must also meet the requirements and propose his move. Right now, we have a teacher who is in the process of moving to become a lecturer at UIN SU." (Results of an interview with IW, October 22, 2020)"

Based on the interview information above, it can be assumed that the implementation of the teacher career development program at MAN 2 Model Medan is carried out based on the proposal of each teacher. Thus, the teacher's internal motivation is very dominant. Aljuhri (2012) explained that the strong internal motivation of the teacher in educating, improving the quality of performance and achievement motivation of teachers. When the teacher has proposed, their proposal is responded to quickly by the leadership.

According to Mr. MS (Deputy Head of Madrasah), that the implementation of the teacher career development program at MAN 2 Model is as follows:

"What is actually being done in this promotion is that I am currently in IV-A. It's just not yet. When I started from III-A, I tried to find useful certificates to increase or increase my credit score. Until in the past in Kisaran I participated in the selection of district instructors. Thank God we succeeded and the only one from the Ministry of Religion who joined the Education Office. So, I educate teachers throughout Asahan Regency for the field of social studies. So actually to increase the rank at the beginning to go up that class already. Then from III-C to III-D we were asked to write papers. I made a class action assessment (CAR). Well, I am a representative from North Sumatra for the field of geography in Cisarua Bogor. The result is that here we can not maximize. At Cisarua Bogor we have entered the top six, they are superior, I say, we are trying to do better. If we are here, the teacher mutation is actually him, we don't actually exist. There are teachers who really want to be transferred to become lecturers. We are actually directing, from this school directing. But the benchmark is the Regional Office, where they direct them. They are made structural first, then they serve there for a few years and then they can mutate. But they already communicated to the Regional Office. But this I heard just again can directly. This is our teacher, Mr. Pandapotan, who is being proposed to be a lecturer at UIN." (Results of an interview with the Deputy Head of Madrasah MAN 2 Model Medan, October 8, 2020).

Based on the interview information above, it can be understood that the implementation of the teacher career development program at MAN 2 Model Medan is carried out by two strategies. First, teachers who want to develop their careers try to collect many certificates of activities that support their professionalism as teachers by participating in various training activities or seminars and discussions. This certificate will then be collected and attached to support the credit score when proposing a promotion. The second is that the teachers try to conduct Classroom Action Research (CAR) at least every semester of a class action research. The results of this study will then be attached as material for consideration in the promotion.

In particular, the researcher saw firsthand that the MAN 2 Model teachers were involved in educational organization activities both in Medan and within the scope of North Sumatra. The organization in question is the Indonesian Teachers Association (IGI). This Certificate (SK) is then valuable for proposing promotions. This organization will then give birth to many activities that can develop teachers' knowledge, insight, and skills. Among the simple outputs of the activity are collected certificates that will be useful if the teacher wants to develop a career. 
According to Mrs. NS (teacher of MAN 2 Model Medan) that the implementation of the teacher career development program is carried out as follows:

"What is done in promotion is proposing a promotion and must meet the requirements for promotion. Madrasas are never made difficult as long as there are opportunities and do not violate the rules. Including me is a mutation from MTsN 2 Medan in 2017." (Results of an interview with the MAN 2 Model Medan Teacher, October 6, 202O).

Based on the results of the interviews above, it can be understood that the implementation of the teacher career development program at MAN 2 Model Medan is first to ensure that the teacher is worthy and meets the requirements for promotion. Therefore, teachers must complete the applicable terms and conditions. After that, the teacher proposed a promotion. In this case, madrasa leaders never make it difficult for teachers who want to develop their careers. Regarding the transfer of teachers at the madrasah, the informant admitted that MAN 2 Model Medan was very open and did not make diving difficult according to the provisions. The informant himself is a transfer from MTsN 2 Medan, which has been successfully transferred since 2017.

According to information from Mr. MY (teacher of MAN 2 Model Medan) that the implementation of the teacher career improvement program at MAN 2 Model Medan is as follows:

"Please propose to be promoted from the principal by completing the promotion files such as a photocopy of diploma, photocopy of the last PAK, photocopy of the last SK, photocopy of SKP for the last 2 years, photocopy of Work Achievement assessments for the last 2 years, photocopy of credit scores from PKG results photocopy of carpet, photocopy of New Cooperative Decree, photocopy of NUPTK card, photocopy of semester program, photocopy of selected RPP, photocopy of physical evidence of SK for division of tasks, photocopy of SK for other assignments, photocopy of seminar certificate, PTK props, PTK as much as 4 pieces and journals, Peg Card, etc. Some MAN 2 teachers have transferred to be principals, some have been transferred to supervisors, some have been transferred to employees at the Regional Office of the Ministry of Religion and then moved to lecturers." (Results of an interview with the MAN 2 Model Medan Teacher, October 8, 2020).

Based on the information above, it can be assumed that implementing the teacher career development program at MAN 2 Model Medan is by proposing or making an application for promotion and completing the required files. Regarding teacher transfer, the informant explained that many of the teachers at MAN 2 Model Medan were transferred to at least three new positions, namely being the head of the madrasa, being a supervisor, and being a lecturer. In this context, Hilmi (2014) added the importance of determining the standardization of mutations in educational institution units by the relevant agencies or agencies such as the Regency/City Ministry of Religion or the Regency/City Education and Culture Office.

The results of the researcher's observations show that many files must be collected in proposing a promotion or teacher transfer. Of course, some of these requirements have been collected long ago. One of the most important elements that make up the completeness of these files is the aspect of scientific work, in this case, namely Classroom Action Research (CAR) and various supporting certificates at seminars and workshops.

According to Mr. PH (teacher of MAN 2 Model Medan) that the implementation of the teacher career development program at MAN 2 Model Medan is as follows:

"To improve teacher careers, we carry out PKB (Continuous Professional Development) activities, create creative works, and conduct Classroom Action Research (CAR). Not many teachers know about teacher transfers. Because the mutation involves the head of MAN 2 Model Medan." (Results of an interview with the MAN 2 Model Medan Teacher, November 17, 2020).

The interview results above show that the implementation of teacher career development at MAN 2 Model Medan is carried out in a first way through Continuous Professional Development (PKB). So, every teacher who wants to develop a career must develop his competence as a teacher 
through various discussion and training activities. Second, in order to increase the rank of teachers, it is necessary to arrange Classroom Action Research (CAR). Conduct research on problems that occur in the classroom, then makes actions to fix the problems that occur. In addition, according to the opinion of the informant that apart from Continuing Professional Development and Classroom Action Research, teachers who want to develop their careers also need to create innovations in the form of creative works that are useful for learning media,

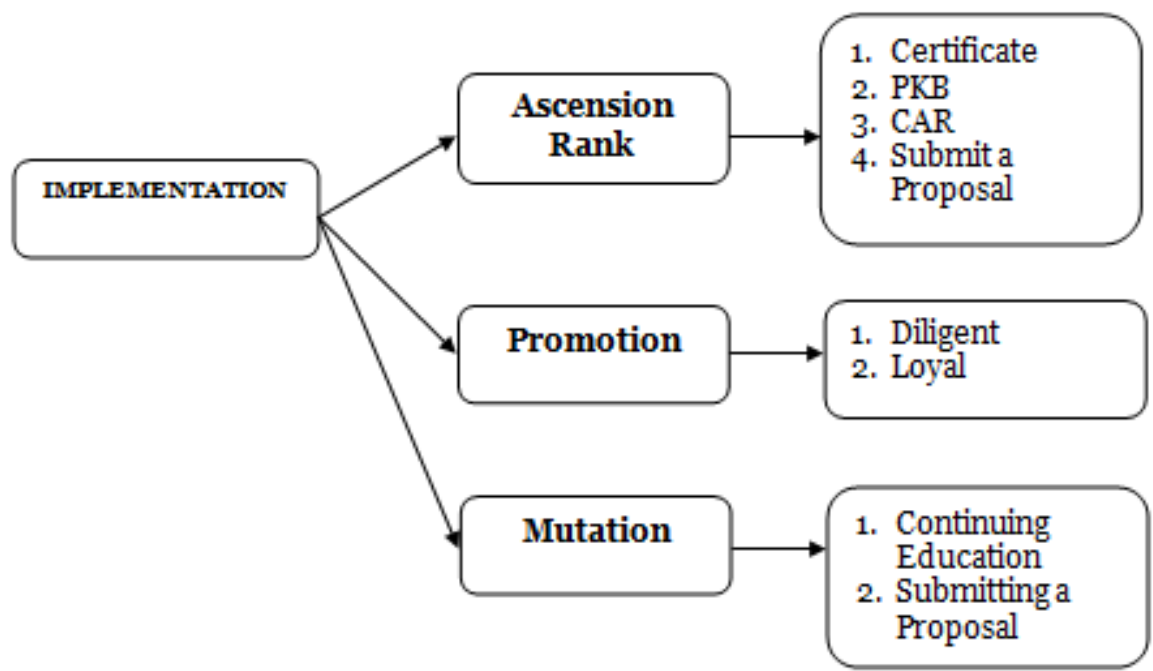

\section{Figure 3. Implementation of Teacher Career Development at MAN 2 Model Medan}

Based on the description and picture above, it can be understood that the implementation of teacher career development is divided into 3 (three) aspects, namely promotion, promotion, and transfer. First, promotions include certificates, continuous professional development (PKB), PTK, and rank proposals. Second, promotion includes diligence and loyalty (dedication). Third, transfers include further education and submitting mutation proposals to agencies (Kanwil Kemenag North Sumatra or Lecturer at UIN North Sumatra Medan).

\section{Evaluation of Teacher Career Development at MAN 2 Model Medan}

Evaluation is an assessment or measurement of the performance that has been implemented (Dewi \& Rusdinal, 2020). In the context of management, evaluation is the final part of management activities (Fathoni, 2016). Evaluation is useful for assessing the level of achievement of planning, organizing, and implementing a work program.

According to the Head of MAN 2 Model Medan, the evaluation of teacher career development at MAN 2 Model 2 Medan was carried out as follows:

"Our supervision is carried out with supervision. So I sometimes go into class and see how the teacher plans and implements and assesses student learning. Then there will be values. We will give awards to teachers who are good at carrying out their duties to motivate other teachers so that they can follow the example." (Results of an interview with $I W$, October 22, 2020).

The interview above indicates that the evaluation of teacher career development programs is carried out directly by the head of the madrasa by going directly into the classroom to see how the learning process is carried out. Evaluation in this context then develops into the values given to the teacher performance appraisal format (Tambunan, 2017). This assessment sheet will then become an essential document for teachers who want to propose promotions.

According to Mr. MS (Deputy Head of Madrasah) that the evaluation of teacher career development at MAN 2 Model 2 Medan is carried out as follows: 
"If we are here, the management, that's our weakness, right. If we build a career, the management is not structured. So we think how we develop it. Most of us are weak in the management section. And I myself admit that the lowest psychological test about management is about management. Because I am the real system, just direct it. I do not want to note this all sorts. Because there are people whose management is good but their work is not good. He's neatly arranged, well, like this, like that, but in reality he doesn't have any work. But his report was the best. Well, I don't want to be like that. I want it, real first, real first. But what is the evidence for that? This needs proof. O... if the principal's motivation is strong. The real problem is that some teachers, especially teachers who are here, exceed the mandatory hours. Now that's a rather narrow time for them to follow the development of their careers."

Based on the information above, it can be assumed that the evaluation of teacher career development at MAN 2 Model Medan has not been carried out optimally. The informant directly acknowledged that the weakness of career development in the MAN 2 Model is related to evaluation. In addition, the obstacles faced by teachers who want to develop a career are the workload which is quite dense, so that they can barely carry out other tasks and often neglect to develop their careers. The next obstacle is the administrative burden of teachers who are too busy so that it takes up much time and the teachers are only busy taking care of the administration. However, the motivation and opportunities provided by the leadership are very good and always encourage teachers to develop their profession.

Furthermore, the evaluation of teacher career development in the MAN 2 Model can be seen in Figure 4 .

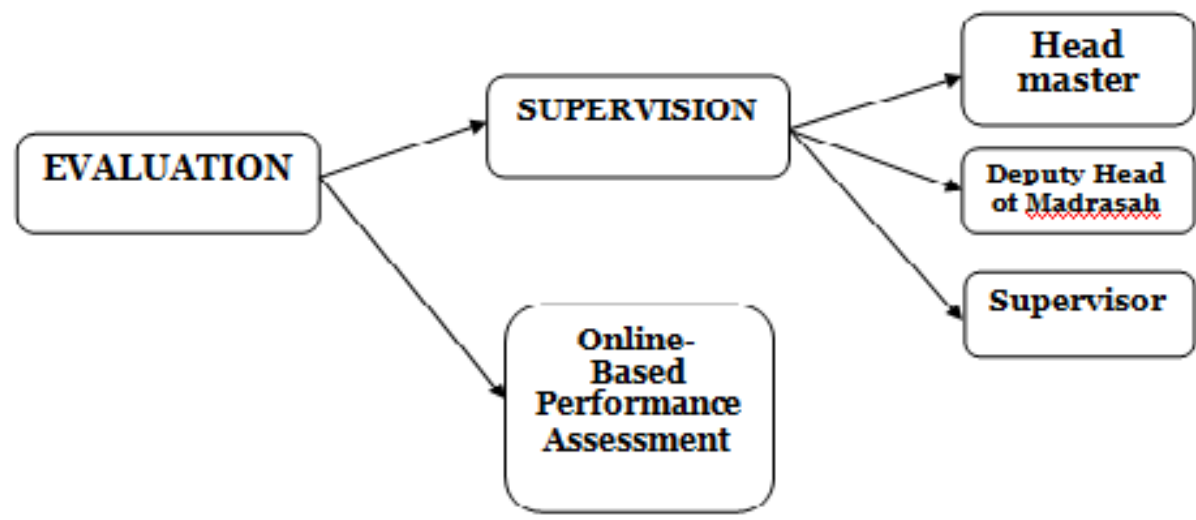

Figure 4. Evaluation of Teacher Career Development at MAN 2 Model Medan

The evaluation of teacher career development at MAN 2 Model Medan includes 2 (two) aspects, namely supervision (by the head of the madrasah, deputy head of madrasa, and supervisor of the Ministry of Religion of Medan City) and online-based performance assessment. According to Sholihah (2018), supervision is closely related to evaluation in the educational process, including teacher career development efforts. Furthermore, Batubara (2016) explains that in addition to supervision, online media can be used as an evaluation tool, namely assessing online-based performance. Thus, the evaluation of teacher career development at MAN 2 Model Medan is innovative and carried out effectively.

\section{CONCLUSION}

The management of teacher career development at MAN 2 Model Medan is carried out effectively. This can be viewed from the aspects; (1) planning for teacher career development in the form of motivation and application of a conducive organizational culture (climate); (2) organizing human resources (HR) for teachers in madrasahs through leadership support, technical meetings, coordination between madrasa leaders and vice-principals involving supervisors to improve teacher qualifications; (3) the implementation of teacher career development is carried out based on promotion, transfer, and promotion; (4) evaluation of teacher career development is carried out based on online-based supervision and teacher performance assessment. This research hopes that it 
can be used as a reference for further research on the management of teacher career development in Islamic educational institutions. This research also has implications for teachers in Islamic educational institutions. This is intended to accelerate career and career development management as educators in madrasas.

\section{REFERENCES}

Alfiansyah, M., et.al. (2020). "Kebijakan Internal Madrasah dalam Meningkatkan Mutu Pendidikan di MI Nurul Ummah Kotagede Yogyakarta” MAGISTRA: Media Pengembangan Ilmu Pendidikan Dasar dan Keislaman, 11(1). https://www.publikasiilmiah.unwahas.ac.id/index.php/MAGISTRA/article/viewFile/3460/3 $\underline{192}$.

Aljuhri, Muhadist. (2012). "Pengaruh Kualitas Kehidupan Kerja dan Lingkungan Kerja Sekolah Terhadap Motivasi Berprestasi” Jurnal Administrasi Pendidikan, 14(1). https://ejournal.upi.edu/index.php/JAPSPs/article/view/6717.

Arman, et.al. (2016). "The effect of school supervisors competence and school principals competence on work motivation and performance of Junior High School teachers in Maros Regency, Indonesia" International Journal of Environmental and Science Education, 11(15). https://core.ac.uk/download/pdf/97978208.pdf.

As'ad. (2017). "Pengembangan Karir Guru di Madrasah Ibtidaiyah (MI) Al-Ifadah Penjaringan Jakarta Utara", Jurnal Wacana Didaktika, 5(1). https://journal.lppmunindra.ac.id/index.php/RDJE/article/view/2068.

Asmani, Jamal Ma'mur. (2013). Tips Menjadi Guru Inspiratif, Kreatif dan Inovatif. Yogyakarta: Diva Press.

Assingkily, Muhammad Shaleh \& Mesiono. (2019). "Karakteristik Kepemimpinan Transformasional di Madrasah Ibtidaiyah (MI) serta Relevansinya dengan Visi Pendidikan Abad 21" MANAGERIA: Jurnal Manajemen Pendidikan Islam, 4(1). http://202.0.92.5/tarbiyah/manageria/article/view/2475.

Assingkily, Muhammad Shaleh \& Nur Rohman. (2019). "Edupreneurship dalam Pendidikan Dasar Islam" JIP Ilmiah http://jurnal.radenfatah.ac.id/index.php/jip/article/view/3721.

Assingkily, Muhammad Shaleh. (2021). Penelitian Tindakan Kelas (Meneliti dan Membenahi Pendidikan dari Kelas). Medan: CV. Pusdikra Mitra Jaya.

Azhari, Riza. \& Abdul Halim Wicaksono. (2017). "Manajemen Pembinaan Karir Sumber Daya Manusia dalam Pendidikan Islam" Jurnal At-Ta'dib, 12(2). https://core.ac.uk/download/pdf/235572887.pdf.

Batubara, Hamdan Husein. (2016). "Penggunaan Google Form Sebagai Alat Penilaian Kinerja Dosen di Prodi PGMI UNISKA Muhammad Arsyad Al Banjari" Al-Bidayah: Jurnal Pendidikan Dasar Islam, 8(1). https://jurnal.albidayah.id/index.php/home/article/view/91.

Creswell, John W. (2009). Research Design Qualitative, Quantitative, and Mixed Methods Approaches. California: SAGE Publications, Inc.

Departemen Pendidikan Nasional. (2000). Kamus Besar Bahasa Indonesia Pusat Bahasa. Jakarta: Balai Pustaka.

Dewi, Asnita Putri \& Rusdinal. (2020). "Perkembangan Karir Guru" Jurnal Manajemen, Kepemimpinan, dan Supervisi Pendidikan, 5(1). https://jurnal.univpgripalembang.ac.id/index.php/JMKSP/article/view/3489.

Dryden, Gordon \& Jeannette Vos. (2001). The Learning Revolution: To Change The Way World Learns. USA: Network Educational Press.

Fathoni, Ahmad. (2016). "Monitoring dan Evaluasi Program Pengembangan Karier Fungsional Guru pada Tiga Sekolah Dasar Negeri di Kabupaten Sukoharjo" Publikasi Ilmiah, 3(1). https://publikasiilmiah.ums.ac.id/xmlui/handle/11617/6696.

Fauzi, Ahmad. (2017). "Strategi Guru Bimbingan dan Konseling dalam Memberikan Layanan Karir Bagi Siswa Kelas IX SMPN 23 Banjarmasin” Skripsi. Banjarmasin: UIN Antasari Banjarmasin. http://idr.uin-antasari.ac.id/9098/.

Hilmi, Anif Iftiros. (2014). "Penerapan Standar Mutasi di Lembaga Pemerintah (Studi Kasus di Lingkungan Kementerian Agama Kota Surabaya)" Skripsi. Surabaya: UIN Sunan Ampel Surabaya. http://digilib.uinsby.ac.id/2025/1/Abstrak.pdf. 
Jawani. (2012). Kompetensi Guru: Citra Guru Profesional. Bandung: Alfabeta.

Nadlir, M. (2013). “Perencanaan Pembelajaran Berbasis Karakter” Jurnal Pendidikan Agama Islam, 1(2): 338-352. https://doi.org/10.15642/jpai.2013.1.2.338-352.

Nurlaila. (2018). "Urgensi Perencanaan Pembelajaran dalam Peningkatan Profesionalisme Guru" Sustainable: Jurnal Kajian Mutu Pendidikan, 1(1). http://jurnal.kopertais5aceh.or.id/index.php/al-qiraah/article/view/124.

Okoroji, L.I. (2014). "Impact of Leadership Styles on Teaching and Learning Process in Imo State" Mediterranean Journal of Social Sciences, 5(4).

Orgovanyi, Judit \& Gajdos. (2016). Teacher's Professional Development on Problem Solving: Theory and practice for Teachers and Teacher Education. Rotterdam: Sense Publishers.

Prabowo, Sugeng Listyo. (2010). "Perencanaan Pembelajaran pada Bidang Studi, Bidang Studi Tematik, Muatan Lokal, Kecakapan Hidup, Bimbingan dan Konseling” UIN Maliki Press. http://repository.uin-malang.ac.id/1616/.

Rachman, Fathor. (2015). "Manajemen Organisasi dan Pengorganisasian dalam Perspektif AlQur'an dan Hadith" Ulumuna, http://ejournal.kopertais4.or.id/madura/index.php/ulumuna/article/view/1628.

Rachmawati, Ryna. (2019). "Pengawas Sekolah/Madrasah: Pengembangan Karir Seorang Pendidik" Jurnal Tatar Pasundan, 13(1). https://bdkbandung.kemenag.go.id/tatarpasundan/jurnal/index.php/tp/article/download/1 $5 / 67$.

Rahayu, Galih Dani Septiyan \& Dida Firmansyah. (2018). "Pengembangan Pembelajaran Inovatif Berbasis Pendampingan Bagi Guru Sekolah Dasar" Abdimas Siliwangi, 1(1). https://www.journal.ikipsiliwangi.ac.id/index.php/abdimas-siliwangi/article/view/36.

Rahmawati, Alvi Dyah. (2018). "Manajemen Pengorganisasian Program Khusus Bahasa Arab di Pare Kediri” Arabi: Journal of Arabic Studies, https://journal.imla.or.id/index.php/arabi/article/view/71.

Ramdani, Agus, et.al. (2019). "Pelatihan Pengembangan Keprofesian Berkelanjutan Bagi Guru Yayasan Pendidikan Pondok Pesantren Yusuf Abdussatar Kediri Lombok Barat” Jurnal Pengabdian Magister Pendidikan IPA, http://jppipa.unram.ac.id/index.php/jpmpi/article/view/357.

Ramli, Efni. (2015). "Tinjauan tentang Mutu Terpadu" Al-Ishlah: Jurnal Pendidikan, 7(2). http://www.journal.staihubbulwathan.id/index.php/alishlah/article/view/44.

Ramli, Efni. (2017). "Membuat Proses Manajemen Berkualitas" Al-Ishlah: Jurnal Pendidikan, 9(1). http://www.journal.staihubbulwathan.id/index.php/alishlah/article/view/1/1.

Rifa'i, Muhammad \& Muhammad Shaleh Assingkily. (2021). "Lisik: Lima Pilar Kebijakan Internal Kepala RA Al Hijrah Badrul Ulum dalam Menciptakan Iklim Belajar Kondusif” Jurnal Obsesi: Jurnal Pendidikan Anak Usia Dini, 5(2). https://doi.org/10.31004/obsesi.v5i2.1098.

Rosyada, Dede. (2017). Madrasah dan Profesionalisme Guru dalam Arus Dinamika Pendidikan Islam di Era Otonomi Daerah. Jakarta: Kencana.

Saefrudin. (2017). "Pengorganisasian dalam Manajemen" Kependidikan dan Syariah, 5(2). http://www.jurnal.staiba.ac.id/index.php/Al-Hikmah/article/view/45.

Sanjaya, Wina. (2009). Perencanaan dan Desain Sistem Pembelajaran. Jakarta: Prenadamedia.

Sarinah. (2016). "Manajemen Pengembangan Karir SDM di Pondok Pesantren Al-Munawwaroh Kabupaten Merangin” Prosiding Jambi International Seminar on Education (JISE), 3-4 April.

Semito, Alex S. Niti. (1992). Manajemen Personalia. Jakarta: Ghalia Indonesia.

Sepriyanti, Nana. (2012). "Guru Profesional adalah Kunci Mewujudkan Pendidikan Berkualitas" Jurnal Al-Ta'lim,

$1(1)$. http://www.journal.tarbiyahiainib.ac.id/index.php/attalim/article/view/8.

Sholihah, Baqiyatush. (2018). "Evaluasi dan Supervisi Program Pembelajaran Al-Qur'an di Sekolah Dasar Islam Bilingual An-Nisa Semarang” Tarbawi: Jurnal Pendidikan Islam, 15(1). https://ejournal.unisnu.ac.id/JPIT/article/view/718.

Sugiyono. (2010). Metode Penelitian Kuantitatif, Kualitatif dan R\&D. Bandung: Alfabeta.

Syafaruddin, et.al. (2006). Ilmu Pendidikan Islam. Jakarta: Hijri Pustaka Utama.

Syafaruddin, et.al. (2020). "Manajemen Pembelajaran Pendidikan Agama Islam di SDIT Bunayya Pandan Kabupaten Tapanuli Tengah" AULADUNA: Jurnal Pendidikan Dasar Islam, 7(1). http://repository.uinsu.ac.id/id/eprint/8966. 
Tambunan, Tumpal B. M. (2017). "Pengembangan Karir Guru Menuju Indonesia Emas" Prosiding Seminar Nasional Pendidikan Dasar Universitas Negeri Medan 2017. https://jurnal.unimed.ac.id/2012/index.php/snpu/article/view/15036.

Tan, Cheng Yong. (2018). "Examining School Leadership Effects on Student Achievement: The Role of Contextual Challeenges and Constraints" Cambridge Journal of Education, 48(1). https://www.tandfonline.com/doi/abs/10.1080/0305764X.2016.1221885.

Wardani, Emilia Neni Kusuma, et.al. (2021). "Kebijakan Sekolah dalam Mendukung Pengembangan Karir Guru SD Negeri 02 Balai Kecamatan Balai Kabupaten Sanggau” Jurnal Pendidikan dan Pembelajaran Khatulistiwa, $10(1)$. https://jurnal.untan.ac.id/index.php/jpdpb/article/view/44455.

Wiganda, Supria. (2014). "Pelatihan Penelitian Tindakan Kelas Bagi Guru-Guru Se-Jakarta Timur" Sarwahita: Jurnal Pengabdian kepada Masyarakat, 11(1). https://doi.org/10.21009/sarwahita.111.01.

Yanti, Eka Fitri, et.al. (2015). "Hubungan Persepsi Karir, Disiplin Kerja, Motivasi Kerja, dengan Kinerja Guru” Jurnal Studi http://jurnal.fkip.unila.ac.id/index.php/JSS/article/view/10961.

Zulaikhah, Nurhimah. (2014). "Hubungan Antara Dukungan Orang Tua dan Orientasi Karir dengan Pengambilan Keputusan Studi Lanjut" Tesis. Surakarta: Universitas Muhammadiyah Surakarta. http://eprints.ums.ac.id/32512/. 